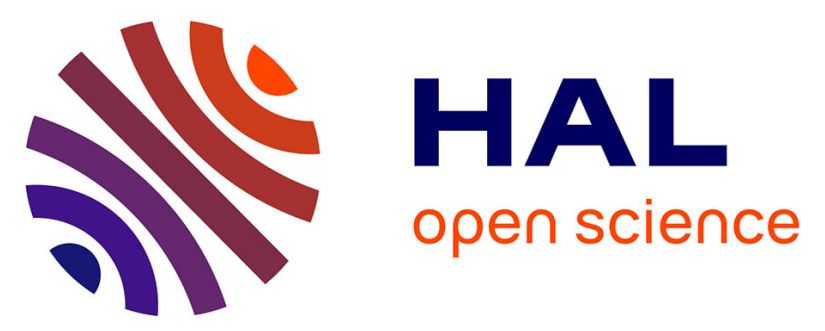

\title{
Levels of dechloranes and polybrominated diphenyl ethers (PBDEs) in human serum from France.
}

Catherine Brasseur, Catherine Pirard, Georges Scholl, Edwin de Pauw, Jean-François Viel, Li Shen, Eric J. Reiner, Jean-François Focant

\section{To cite this version:}

Catherine Brasseur, Catherine Pirard, Georges Scholl, Edwin de Pauw, Jean-François Viel, et al.. Levels of dechloranes and polybrominated diphenyl ethers (PBDEs) in human serum from France.. Environment International, 2014, 65, pp.33-40. 10.1016/j.envint.2013.12.014 . hal-01004642

HAL Id: hal-01004642

https://hal-univ-rennes1.archives-ouvertes.fr/hal-01004642

Submitted on 13 Jun 2014

HAL is a multi-disciplinary open access archive for the deposit and dissemination of scientific research documents, whether they are published or not. The documents may come from teaching and research institutions in France or abroad, or from public or private research centers.
L'archive ouverte pluridisciplinaire HAL, est destinée au dépôt et à la diffusion de documents scientifiques de niveau recherche, publiés ou non, émanant des établissements d'enseignement et de recherche français ou étrangers, des laboratoires publics ou privés. 
1 Levels of dechloranes and polybrominated diphenyl ethers (PBDEs) in human serum from France

3

4

5

Catherine Brasseur $^{\mathrm{a}, \mathrm{b}}$, Catherine Pirard ${ }^{\mathrm{a} 1}$, Georges Scholl ${ }^{\mathrm{b}}$, Edwin De Pauw ${ }^{\mathrm{b}}$, Jean-François Viel ${ }^{\mathrm{c}}$, Li Shen $^{d}$, Eric J. Reiner ${ }^{d}$,Jean-François Focant ${ }^{a}$

${ }^{a}$ CART, Organic and Biological Analytical Chemistry, Chemistry Department, University of Liège, Allée du 6 août, B6c, Sart-Tilman, B-4000 Liège, Belgium.

${ }^{\mathrm{b} C A R T}$, Mass Spectrometry Laboratory, Chemistry Department, University of Liège, Allée du 6 août, B6c, Sart-Tilman, B-4000 Liège, Belgium.

'INSERM U1085, EpidemiologicalResearch on Environment, Reproduction and Development, Faculty of Medicine, University of Rennes, Campus de Beaulieu, 35042 Rennes, France.

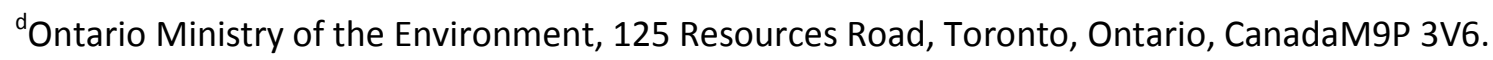
(6)

Corresponding author :

Jean-François (Jef) Focant

University of Liège, Allée du 6 août, B6c, B-4000 Liège (Sart-Tilman), Belgium

Ph: +32 (0)4 36635 31, Cell: +32 (0)495 9295 64, E-mail: JF.Focant@ulg.ac.be

\footnotetext{
${ }^{1}$ Present address: University Hospital Center (CHU), Clinical Toxicology, University of Liège, SartTilman, B-4000 Liège, Belgium
} 


\section{Abstract}

Human exposure to dechloraneshas been evaluated in Western Europe (France) with the analysis of Dechlorane Plus (DP), Dechloranes (Dec) 602, 603, 604, Chlordene Plus (CP) and Mirex in 48 serum samples collected between 2003 and 2005. While no production source has been identified in Europe until now, detection frequencies for all investigated dechloranes were high, except for Dec 604 whichwas below detection limit for all samples. The mean DP concentration was $1.40 \pm 1.40 \mathrm{ng} / \mathrm{g}$ lipid weight (Iw), lower than levels reported in serum from Chinese population, but higher than levels reported in Canadian human milk.To the best of our knowledge, this is the first time $\sum_{5}$ dechloranelevels are reported for human serum. A specific pattern of contamination was found (Dec $603>$ DP > Mirex > Dec $602>\mathrm{CP}$ )compared to other biota samples that have been analyzed from Europe,with Dec 603 as the most abundant dechlorane (meanlevel: $2.61 \pm 2.63 \mathrm{ng} / \mathrm{g} \mathrm{lw}$ ). Dec 603 and CP levels were correlated with age and with levels of some bioaccumulative organochlorine pesticides (OCPs). These results indicate that bioaccumulation properties should be further investigated and taken in consideration when assessing human exposure to dechloranes.For comparison purposes, polybrominated diphenyl ether(PBDE) levels were also measuredfor BDE-47, $-99,-100,-153$ and -154 in the serum samples. As expected, BDE47 and BDE-153 were the major congeners with mean levels of $2.06 \pm 1.80 \mathrm{ng} / \mathrm{g} \mathrm{lw}$ and 1.39 $\pm 0.97 \mathrm{ng} / \mathrm{g} \mathrm{Iw}$, respectively. The mean $\sum_{5} \mathrm{PBDE}$ levels $(4.32 \pm 2.99 \mathrm{ng} / \mathrm{g} \mathrm{lw})$ was in the range typical ofWestern Europe levels, but lower than the mean $\sum_{5}$ dechlorane levels $(6.24 \pm 4.16$ $\mathrm{ng} / \mathrm{g}(\mathrm{w})$. These results indicate that the attention to dechloranes should be continued if research indicates toxicological concerns.

\section{Keywords}


47 Dechloranes; human biomonitoring; flame retardants; blood serum; PBDEs 


\section{INTRODUCTION}

Dechlorane or Mirex $\left(\mathrm{C}_{10} \mathrm{Cl}_{12}\right)$ was extensively used as a pesticide as well as an additive flame retardant (FR) in the USA during the 1960s and the 1970s.It was bannedin the USA in 1978 because of its toxicity, persistence and high potential for bioaccumulation(Kaiser, 1978). Consequently, other related compounds such as Dechlorane Plus (DP, $\mathrm{C}_{18} \mathrm{H}_{12} \mathrm{Cl}_{12}$ ), Dechlorane 602 (Dec 602, $\mathrm{C}_{14} \mathrm{H}_{4} \mathrm{Cl}_{12} \mathrm{O}$ ), Dechlorane 603 (Dec 603, $\mathrm{C}_{17} \mathrm{H}_{8} \mathrm{Cl}_{12}$ ), Dechlorane 604 (Dec 604, $\left.\mathrm{C}_{13} \mathrm{H}_{4} \mathrm{Br}_{4} \mathrm{Cl}_{6}\right)$ and Chlordene Plus $\left(\mathrm{CP}, \mathrm{C}_{15} \mathrm{H}_{6} \mathrm{Cl}_{12}\right)$, patented by Hooker Chemicals and Plastics Corp. (Hooker; currently OxyChem, Niagara Falls, New York), became candidates to replace Mirex. All these compounds share a bicyclo $[2,2,1]$ heptene structure,resultingfrom a DielsAlder reaction between one or two hexachlorocyclopentadiene molecules (HCCPDs) with various cyclic dienophiles.They all possess flame retardant propertiessimilar to Mirex(International Programme on Chemical Safety, 1984). Whereas the use of DP as a flame retardant (electrical wires, cables coating, computers and polymers) is well established (Betts 2008), listed as a high production volume chemical in the USA (US Environmental Protection Agency, 2006)and as a low production volume chemical in EU (Sverko et al., 2011), little information is available for the use of the other dechloranes. Dec 602 and Dec 604 are reported as flame retardant additives for polymeric products and they are listed on the Nondomestic Substances List published by Environment Canada (Canadian Environmental Protection Act, 1999), indicating their current use in commercial products. On the contrary, no direct applications have been reported for Dec 603 or CPto date. They were only referenced as impurities found in technical organochlorine pesticides (OCPs)(Shen et al., 2011).All these compounds are unregulated compounds and representa possible alternative to other regulated FRs such as the polybrominated diphenyl ethers (PBDEs). 
The environmental occurrenceof dechloranes was first reported in 2006 in North

Americawhen DP was detected in air, sediment and fish samples from the Laurentian Great Lakes (Hoh et al., 2006). Different studies were conducted in this particular area (Qiu and Hites 2007; Sverko et al., 2007)potentially contaminateddue to the proximity of the manufacturer Oxychem, localized on the Niagara River, the main connecting channel between Lake Ontario and Lake Erie. A relationship between environmental DP levels and the distance from the manufacturing plant was demonstrated, as well as with the local population density (Hites et al., 2010), possibly reflecting the use of DP in electrical equipment. In 2010, other dechloranessuch as Dec 602, 603 and 604 were reported in sediment and fish samplesfrom the same area (Shen et al., 2010). CP was later detected in sediments(Shen et al., 2011).Similar studies were also conducted in China.In 2010, Wang et al.collected samples from the vicinity of an important DP manufacturing plant operating since 2003 (Anpon Electrochemical Company,located in Huai'an,Northwest of Shanghai). The influence of the production planton environmental contamination levels in this region was demonstrated. DP levels were also correlated to the proximity to e-waste recycling plants and various industrialareas (Qi et al., 2010; Wang et al., 2011; Yu et al., 2010).Additionally to DP, Dec 602 was detected in air, soil andsediment samples while Dec 603 and Dec 604 were below detection limits(Wang et al., 2010).

Even though the number of studies is still small, and measurements around other potential manufacturing plants have still to be conducted, additional data collected in Korea, Brazil, North Africa, Spain and Germany (de la Torre et al., 2012; de la Torre et al., 2011; Kang et al., 2010; Munoz-Arnanz et al., 2012; Sühring et al., 2013) indicate that DP and related compounds should be considered as possible worldwide contaminants. Furthermore, Möller et al. (2010)reported DP in air sampled in the Atlantic Ocean and suggested that this 
compound waspossibly subjectto long range atmospheric transport. The same is observed for Dec 602 as it was recently detected in Arctic Beluga whales (Shen et al., 2012).Two recent review papers described sources, occurrence and behavior of dechloranes in the environment, concluding on the need of more research dedicated to the production of data on exposure and toxicity (Sverko et al., 2011; Xian et al., 2011).Additionally tothe fact of considering environmental contamination and geographical distribution, abetter understanding of the behavior of DP and related compounds in terms of bioaccumulation and biomagnification is still needed. This is important since structurally similar Mirex was banned and added to the Persistent Organic Pollutant List of the Stockholm convention because, among other criteria, of its bioaccumulative potential(Stockholm Convention, 2001).A collection of limiteddata for aquatic and terrestrial biota was recently reported by Feo and al. (2012). It highlighted the lack of information on the toxicity of DPto aquatic and terrestrial organisms.

Even more importantly, virtually nohuman biomonitoringdata are available for any of the dechloranes. The assessment of internal dose exposure by mean of measurementsof these toxicants in human tissues or fluids is currently unavailable.There have only been a coupleof reports published concerning studies conducted in China and Canada. Serumand collected hair samples from workers ata Chinese e-waste recycling facility were analyzed to evaluate DP exposure. Results from these hair samples suggested that direct ingestion of dust could be considered as a major route of DP exposure of the workers (Zheng et al., 2010).Inthe firststudy to report DP levels in human serum, DP was detectedatconcentrations ranging from 7.8 to $465 \mathrm{ng} / \mathrm{g}$ lipid weight (Iw)(Ren et al., 2009).Lower levels were later reportedfora population living in an urban area of South China (2.7 to $91 \mathrm{ng} / \mathrm{g}$ lw)(Yan et al., 2012) or in a Halogenated Flame Retardant (HFR) production area of Northeastern China (1.4 to $11 \mathrm{ng} / \mathrm{g}$ 
Iw) (He et al., 2013). DP levels were also reported in Canadian human milk, ranging from non-detected (nd) to $8 \mathrm{ng} / \mathrm{g} \mathrm{Iw}$ (Siddique et al., 2012). Noneof these studies however reported data for the other dechloranes which have been reported to be even more bioaccumulative than DP. Only a recent study by Cequier at al. (2013) reported DP, Dec 602 and 603 levels in human serum on a few individual serum samples $(n=10)$ from Norway.

The present study had two objectives. The first was to adapt an existing analytical procedurebased on solid-phase extraction (SPE) and gas chromatography coupled to high resolution sector mass spectrometry (GC-HRMS) to isolate and measure levels of Mirex, DP, Dec 602, Dec 603, Dec 604, and CP in human serum samples. The secondwas to measure levels of these compounds in human serum samples fromWestern Europe (France)for which data on levels ofselected persistent organic pollutants (POPs) such as OCPs were previously reported (Viel et al., 2011). Levels of selected PBDEs have also been measured in the present study to allow comparison with dechlorane levels.

\section{MATERIALS AND METHODS}

\subsection{Serum samples}

A total of 48 banked human serum samples of which 24 males and 24 females (mean age 57 \pm 13 years, age range $28-86$ years) were analyzed for this study. They were collected in France between 2003 and 2005, from people living in the area of a municipal solid waste incinerator in Besançon. Further details about samples and the ethical approval of the study are described in another study (Viel at al., 2011).

\subsection{Lipid content determination}


Enzymatic lipid determinations of unknown samples were performed by a sub-contractor

143

clinical laboratory on a dedicated $1 \mathrm{~mL}$ serum sub-sample. Four types of lipids were targeted and measured: triglycerides, total cholesterol, non-esterified (free) cholesterol, and phospholipids B. Sample sizes were as follow: triglycerides $(2 \mu \mathrm{L})$, total cholesterol $(2 \mu \mathrm{L})$, non-esterified (free) cholesterol $(50 \mu \mathrm{L})$, and phospholipids $B(20 \mu \mathrm{L})$. A well documented summation method was used to estimate the total lipid concentration (Akins et al., 1989). The total lipid content was expressed in $\mathrm{g} / \mathrm{L}$. For the inter-conversion of volumetric and gravimetric data, a value of $1.026 \mathrm{~g} / \mathrm{mL}$ was used for serum specific gravity.

\subsection{Chemicals}

Syn-DP, anti-DP and syn-DP ${ }^{13} \mathrm{C}_{10}$ labeled (99\%)standards weresupplied byCambridge Isotope Laboratories (CIL, Andover, MS, USA). Dec 602 (95\%), Dec 603 (98\%) and Dec 604 (98\%) were purchased from Toronto Research Chemical Inc. (Toronto, ON, Canada) and CP was from Wellington Laboratories (Guelph, ON, Canada).Mirex was purchased from Cluzeau InfoLabo (France).The EC-4058 solution of PCBs mixture containing CB-209 ${ }^{13} \mathrm{C}_{12}(99 \%)$ andthe EC-1414 solution ofCB-80 ${ }^{13} \mathrm{C}_{12}$ (99\%), from $\mathrm{CIL}$, were used assurrogateand instrumental (recovery) labeled standards, respectively. For BDE-47, 99, 100, 153 and 154 measurements, the BDECVS-F calibration solutions, the MBDE-MXFS labeled surrogate stock and the MBDE-MXFR labeled recovery stock $\left({ }^{13} \mathrm{C}_{12}\right.$ standards)werepurchased from Wellington Laboratories. Hexane was Picograde reagent (LGC Promochem, Wesel, Germany). Nonane (analytical standard grade, Fluka) was purchased from Sigma-Aldrich (St Louis, MO, USA). Anhydrous sodium sulfate was from Acros Organics (Geel, Belgium) and sulphuric acid $95-97 \%$ was Baker analyzed reagent (J.T. Baker, Deventer, Holland).Silica gel $60(0.063-0.200 \mathrm{~mm})$ for column chromatography was purchased from Merck (Darmstadt, Germany). 


\subsection{Sample preparation}

168 Sample sizes of $10 \mathrm{~g}$ were extracted using solid-phase extraction (SPE) on non-end capped isolute C18 cartridges (1g/6 mL) (Argonaut-Sopachem, Brussels, Belgium). The C18 cartridges were eluted with $3 \times 5 \mathrm{~mL}$ of hexane. More details on the SPE protocol can be found elsewhere (Focant et al., 2006). The $15 \mathrm{~mL}$ hexane extracts were then loaded on a multilayers column made, from bottom to top, of $2 \mathrm{~g}$ of $22 \%$ sulphuric acid silicagel, $1 \mathrm{~g}$ of activated silica and $1 \mathrm{~g}$ of sodium sulfate. Further elution with $15 \mathrm{~mL}$ of hexane was performed. The evaporation of the pooled fractions was carried out using a PowerVap 6 system (Fluid Management Systems Inc., Watertown, MA, USA) equipped with specific evaporation tubes to which GC vials are screwed and can easily be disconnected once the final evaporation volume of $500 \mu \mathrm{L}$ is reached. After adding the keeper solvent (nonane), gentle room temperature evaporationin a dust protected hood was performedto reach a final volume of $10 \mu \mathrm{L}$ of nonane. Procedural blank samples consisted in $10 \mathrm{~mL}$ of Milli$\mathrm{Q}^{\circledR}$ water (Millipore, Brussels, Belgium)that followed the same procedure. A blank was included with each series of 8 unknown samples.

\subsection{Measurement}

Samples were analyzed with a GC-HRMSsystem (MAT95 XL, Thermo FinniganMAT, Bremen, Germany) connected by a heated transfer line $\left(275^{\circ} \mathrm{C}\right)$ to a CE Trace $\mathrm{GC}$ (ThermoQuest) equipped with anA2000S autosampler (Thermo). The GC column was a ZB-5 (15m x 0.25mm I.D., $0.25 \mu \mathrm{m} \mathrm{df)} \mathrm{(Phenomenex,} \mathrm{Utrecht,} \mathrm{The} \mathrm{Netherlands).} \mathrm{Helium} \mathrm{was} \mathrm{used} \mathrm{as} \mathrm{the} \mathrm{carrier}$ gas at a constant flow rate of $1 \mathrm{~mL} / \mathrm{min}$. One and two microliters of the final extract (for dechloranes and PBDEs analysis, respectively) were injected into a split/splitless injector held 
at $280^{\circ} \mathrm{C}$, in splitless mode.For dechlorane measurements, the GC oven temperature was maintained at $140^{\circ} \mathrm{C}$ for $2 \mathrm{~min}$, ramped at $30^{\circ} \mathrm{C} / \mathrm{min}$ to $280^{\circ} \mathrm{C}$ then at $5^{\circ} \mathrm{C} / \mathrm{min}$ to $300^{\circ} \mathrm{C}$ and held for $10 \mathrm{~min}$. For PBDE measurements, the GC oven temperature was maintained at $140^{\circ} \mathrm{C}$ for $1 \mathrm{~min}$, ramped at $15^{\circ} \mathrm{C} / \mathrm{min}$ to $180^{\circ} \mathrm{C}$, then at $10^{\circ} \mathrm{C} / \mathrm{min}$ to $290^{\circ} \mathrm{C}$ and finally at $80^{\circ} \mathrm{C} / \mathrm{min}$ to $350^{\circ} \mathrm{C}$ and held for $2 \mathrm{~min}$. The $\mathrm{MS}$ ion source temperature was $250^{\circ} \mathrm{C}$ and Electron Ionization (EI) was performed with 70eV. TheHRMS instrument was operated in the selected ion monitoring(SIM) mode. Two ions were monitored for both native and labeledspecies at $\mathrm{m} / \mathrm{z} 271.8102 / 273.8072$ fordechloranes,276.8269/278.8240 for syn-DP ${ }^{13} \mathrm{C}_{10}, \quad 295.9157 / 297.9127$ for $\quad$ surrogateCB-209 ${ }^{13} \mathrm{C}_{12}$ and $\quad 301.9626 / 303.9597$ for recovery ${ }^{13} \mathrm{C}_{12} \mathrm{CB}-80$.For $\mathrm{PBDE}$ measurements, the monitored ions were $\mathrm{m} / \mathrm{z}$ 483.7131/485.7111 and 495.7533/497.7513 for native and labeled tetra-BDEs (47 and recovery 77), $403.8046 / 405.8026$ and $415.8449 / 417.8429$ for penta-BDEs (99 and 100), 481.7151/483.7131 and 493.7553/495.7533 for hexa-BDEs (153, 154, and recovery 138).Monitored ions were chosen based on signal intensity, specificity and jump between $\mathrm{m} / \mathrm{z}$ values allowedduring the analysis according to the magnet settling time.Samples were analyzed randomly. Calibration stabilitywas ensured by injectingbothlow and high level calibration points ofthe curve every 20 samples. Both instrumental and procedural blanks were monitored. More details regarding the GC-HRMS procedure can be obtained in a previous report (Focant et al., 2001).

\subsection{Quality assurance and quality control (QA/QC)}

All samples were processed in an ISO17025 BELAC accredited laboratory. The compounds were identified based both on retention time of the corresponding standard with maximum variation of $2 \mathrm{sec}$ and mass spectral data. Isotope ratio between the two monitored ions was 
checked to ensure proper identification. The limits of quantification of the method

(LOQ)were calculated based on a signal-to-noise $(\mathrm{S} / \mathrm{N})$ ratioequal to 6.For compounds detected in procedural blanks, the mean procedural blank value was subtracted from the samples and the limit of quantification was set at 3 times the standard deviation of the procedural blank.A QC serum sample was included with each series of 8 unknown samples. This internal QC was made of a pool of non-fortified human serum of 1030 adults (30-65 years old), collected between March and July 2005 in 8 different areas in France(Frery et al., 2007).

\subsection{Statistical analyses}

Statistical analyses were performed using XLSTAT 2013. According to the Shapiro wilk-test, the data significantly deviated from normal distribution $(p<0.05)$. The non-parametric Spearman's rank correlation coefficients $\left(r_{s}\right)$ were calculated to assess relationships between the different levels of compounds as well as with age. The Mann-Whitney $U$ test was used for comparison between males and females or younger and older people. Concentrations were lipid normalized before statistical analysis and samples below LOQ were assigned with the LOQ value.

\section{RESULTS AND DISCUSSION}

\subsection{Method performances}

The sample preparation procedure was derived from our routine approach for measurement of selected polychlorinated dibenzo-p-dioxins (PCDDs), polychlorinated dibenzofurans (PCDFs), and polychlorinated biphenyls (PCBs) in human serum (Focant et al., 2006).Recovery rates were calculated using $C B-80{ }^{13} \mathrm{C}_{12}$ as instrumental standard. The 
average surrogate standard recoveries ranged from $40 \%$ to $71 \%$ forCB-209 ${ }^{13} \mathrm{C}_{12}$ and from $33 \%$ to $61 \%$ forsyn-DP ${ }^{13} \mathrm{C}_{10}$. Because of the comparable structures and lipophilicity of the 239 dechloranes, similar recovery rates can be expected for the other dechloranes. These values 240 are similar to what has previously been reported for dechlorane measurements in 241 environmental and biological samplesusing similar analytical approaches (Shen et al., 2010;

242 Shen et al., 2011;Baron et al., 2012). A more precise calculation would require proper ${ }^{13} \mathrm{C}$ -

243 labeled internal standard to be used, but these compounds are not yet available. For PBDEs, 244 recovery rates ranged from 55 to $81 \%$, in accordance to one of our previous studies (Pirard 245 et al., 2003).

246 For dechloranes, retro Diels-Alder HCCPD ionfragments were selected for quantification and 247 isotope ratio checks. Typical chromatograms for dechloranes in standard solutions and in real 248 serum samples are available in supplementary data (Figure S1). The variation of the isotope 249 ratio between the two monitored ions was within $\pm 15 \%$ and $\pm 30 \%$ of the theoretical value for 250 PBDEs and dechloranes, respectively. LOQsof the methods, on a lipid weight basis, are listed 251 in Table 1. The method allowed the measurement of all analytes, except Dec 604 for which 252 the instrumental LOD of $0.3 \mathrm{pg} / \mu \mathrm{L}$ was not suited to the very low levels in serum samples. 253 QC charts obtained for dechloranes and PBDEs, for the 6 QC samples that were analyzed 254 during the time of unknown sample analyses are shown in Figure 1. Values were 255 normalizedand presented in z-score units. Upper and lower control limits (UCL/LCL) 256 corresponded to $3 \sigma$, while warning limits were set at $2 \sigma$. For each compound, each QC was 257 included within $2 \sigma$ of the total average. The mean \pm SD (ng/g Iw) of dechlorane and PBDE 258 levels in the non-fortified pool serum are reported in Table 2.No (certified) reference 259 materials are available so far for dechloranes. The reproducibility of the measurements was 260 acceptable with CV ranging from $11 \%$ to $32 \%$, with CV for BDE-47 slightly higher (37\%) due to 
lower control of the blank levels in our laboratory at the time of the study. Despite the fact

262

263 that syn-DP ${ }^{13} \mathrm{C}_{10}$ was used, the CV for syn-DP was higher than for other dechloranes for which no ${ }^{13} \mathrm{C}$-labeled internal standards were available. Furthermore, for the other dechloranes, when quantifications were tested on either syn-DP ${ }^{13} \mathrm{C}_{10}$ or CB-209 ${ }^{13} \mathrm{C}_{12}$, better correlation coefficients and lower CVs were always obtained with $\mathrm{CB}-209{ }^{13} \mathrm{C}_{12}$. This was verified by calibration checks over time.As reported also by others, stability issues might be present for the syn-DP ${ }^{13} \mathrm{C}_{10}$ standard solution, but this requires further investigation to be verified.

\subsection{Levels of dechloranesin human serum}

DP, Dec 602, Dec 603, CP, and Mirex were detected in almost all the serum sampleswhile Dec 604 was below detection limit for all samples.Detection frequency, mean, median, and range values are reported in Table 1. DP levels (median: 1.20 , range: $\mathrm{nd}-7.04 \mathrm{ng} / \mathrm{g} \mathrm{Iw}$ ) are higher but consistent with levels reported by Siddique et al. (2012)in their study on human milk from Canada (median: 0.6, range: $\mathrm{nd}-8.0 \mathrm{ng} / \mathrm{g} \mathrm{lw).} \mathrm{Studies} \mathrm{from} \mathrm{China} \mathrm{reported} \mathrm{DP}$ levels with median values10 to 40 times higher for e-waste recycling plant workers (Ren et al., 2009) and 5 times higher for women living close to e-waste recycling sites (Ben et al., 2013). For both of these studies, direct occupational exposure to DP was expected according toits use andproduction for the electronic market in North America and China.The reason for the presence of dechloranes in human serum samples from Europeis not clear. DP, Dec 602 and Dec 603 were also detected in human serum samples from Norway (Cequier et al., 2013). Direct exposures by contact to commodities containing dechloranes and/or long range transport are possible hypothesis but no robust data are available so far to further explore them. Dec 603 surpassed all other dechloranes in terms of concentration (median 
value of $2.01 \mathrm{ng} / \mathrm{g} \mathrm{Iw}, 39 \%$ of the $\sum_{5}$ Dechloranes). Mirex, the banned product, was present at measurable levels in all samples with a median value of $1.06 \mathrm{ng} / \mathrm{g} \mathrm{lw}$. No literature data are available for comparison of relative concentration pattern of Mirex, DP, Dec 602, Dec 603, Dec 604, and CP levels in serum. To our knowledge, this study is the first to report levels for these $\sum_{5}$ dechloranes $(5.21 \mathrm{ng} / \mathrm{g} \mathrm{Iw})$ in human serum. Levels ofMirex were rarely reported in human serum studies focusingon OCPs, as Mirexconcentrations are usually below LODs(Kang and Chang, 2011). The comparison within the dechlorane family showed a relative concentration pattern of Dec $603>$ DP > Mirex > Dec $602>\mathrm{CP}$ (Figure2).Among the few studies available on dechlorane levels, this is the first time Dec 603 is reported as the most abundant dechlorane. In biota studies, Mirex usually remains the most abundant dechlorane, with levels 10 to 40 times higherthan the other dechloranesin samples from Canada or Brazil, while a smaller difference is observed in samples from Spain (de la Torre et al., 2012; Guerra et al., 2011; Shen et al., 2010). In our study, Mirex and DP were detected at relatively similar levels, higher than Dec 602. Similar results were reported by de la Torre et al. (2012) for their study on Franciscana Dolphin from Brazil. Mirex was the similar to levels reported in the present study, and around 2 times higher than levels of Dec 602 and Dec 603,the only other dechloranes reported in that study. DP was detected at lower levels than Dec 602 in bird eggs or fish samples from both Spain and Canada (Baron et coefficients ( $\left.\mathrm{K}_{\mathrm{ow}}\right)$ and bioconcentration factors (BCF) (Shen et al., 2010). These results support the hypothesis that not only the geographical localization influences the pattern of 
contamination levels. The higher level of Dec 603 compared to Dec 602 could be related not only to a higher level of exposure but also to a specific biotransformation or bioaccumulation in mammals or humans. In the study of de la Torre et al. (2012) on mammals, they obtained the highest biotransformation half-life (HL; day) value for Dec 603 (138000), followed by DP $(33100)>C P(12630)>\operatorname{Dec} 602$ (2752) > Dec 604 (1219) > Mirex (109).

Another mammalstudy on Artic Beluga whales reported Dec 602at low levels (0.08 to 0.3 ng/g Iw) while DP, Dec 603, and Dec 604 were not detected (Shen et al., 2012).The exposure level certainly remains an important factor to take in consideration, like it is the case for biotransformation as dechlorinated products were also detected. Therefore, more investigations are needed to fully integrate factors such as exposure level, bioavailability, bioaccumulation, and biotransformation to better understand the relative distribution of the various dechloranes in human serum samples.

Dec 602 was detected in all human serum sampleswhile Dec 604 was not detected at all. Such a situation was also reported in otherbiota studies (Baron et al., 2012; de la Torre et al., 2012 ; Shen et al., 2012). Although the presence of Dec 604 in samples is likely dependenton bioaccumulation parameters, it could also be a possible marker of production source proximity. The study ofShen et al. in Canada (2010) demonstrated a relationship between samples located in the Niagara area, close to the manufacturer Oxychem, and contamination of Dec 602 and Dec 604.Similar trends obtained for Dec 602 and Dec 604 possibly reflected usage patterns of these compounds in some flame retarded polymers. A production source in Europe is nevertheless possible as Dec 604 has been already reported in biota samplesfromSpain (Guerra et al., 2011).

Spearman's correlation coefficients were used to investigate possible relationships between the different dechlorane levels(Table 3). Correlation values with statistical significance( $p<$ 
$0.05^{*}$ or $p<0.01^{* *}$ ) were obtained between all the reported dechloranes, except between DP and Mirex. CP and Dec 603 showed the strongest correlation $\left(r_{\mathrm{s}}=0.83\right.$ with $\left.p<0.01\right)$, as well as CP and Dec $602\left(r_{s}=0.71\right.$ with $\left.p<0.01\right)$. The lowest but significant value $\left(r_{\mathrm{s}}=0.29\right.$ with $p<0.05$ ) was obtained between DP and Dec 602. DP has been reported as a potential flame retardant in usein Europe. The reason for the lack of correlation between DP and Mirex is not clear. One can think that although DP is exclusively used as a FR, Mirex was also mainly used as a pesticide and this would therefore result in a different type of exposure. The ban of Mirex could also be impacting the correlation, but should also do for the other dechloranessuch as Dec 602, Dec 603, and CP, unless the novel aspect of their use counterbalances this effect. Whether the presence of dechloranes in human serum is related to their use as FRs in Europe or from use as pesticides remains undefined. Balance between contamination from exposure and bioaccumulation must be considered. Additionally, one has to keep in mind that no production sources have been located in Europe to date, opening the discussion to possible long range transport as another source of exposure.

\subsection{Comparison of dechlorane and PBDE levelsin human serum}

Levels of BDE-47, 99, 100, 153 and 154 are listed in Table 1.The $\sum_{5}$ PBDE levels ranged from 1.63 to $15.02 \mathrm{ng} / \mathrm{g} \mathrm{Iw}$, with a median value of3.46 ng/g Iw.BDE-47 and BDE-153 were the most abundant PBDEs with a contribution of $45 \%$ and $33 \%$ to the total amount, respectively. The relative concentration pattern is BDE-47 >BDE-153>BDE-99 $\approx$ BDE-100>BDE-154 (Figure 2). Similar results with predominant BDE-47 and BDE-153 have been reported in human serum studiesfrom Sweden, Korea, Greece or Slovakia(Chovancova et al., 2012; Guvenius et al., 2003; Kalantzi et al., 2011; Lee et al., 2007). Several studiesfrom both the USand Europe 
differently reported patternsrelated to the commercial PentaBDE mixture content, with a major contribution of BDE-47 and BDE-99 (Antignac et al., 2009; Frederiksen et al., 2009; Sjödin et al., 2004).Such differences may be related to possible variations in routes of exposure and use of PBDE mixtures.As for the case of the Canadian milk samples (Siddique et al., 2012), the median DP level $(1.20 \mathrm{ng} / \mathrm{g} \mathrm{lw})$ was lower than the $\sum_{5} \operatorname{PBDEs}(3.46 \mathrm{ng} / \mathrm{g} \mathrm{lw})$. However, once other dechloranes are included, the mean $\sum_{5}$ dechlorane level(5.21ng/g Iw) ishigher than the mean $\sum_{5}$ PBDE level. Dec 602, Dec 603, and CP therefore appear to be important congeners to measure if one has to estimate a global dechlorane exposure. Focusing on DP only might lead to an under estimation of the real dechlorane exposure. Such data indicate that the attention devoted to dechloranes should be continued if research indicates toxicological concerns.

PBDE levels were correlated (Table 3) except for BDE-154 that was only correlated with BDE$100\left(r_{s}=0.31, p<0.05\right)$. The $\sum_{5}$ PBDE level was slightly lower than the $\sum_{5}$ dechlorane level (Table 1) with median values of $3.46 \mathrm{ng} / \mathrm{g} \mathrm{Iw}$ and $5.21 \mathrm{ng} / \mathrm{g} \mathrm{Iw}$, respectively. Potential relationships between dechloranes and PBDEs levels were evaluated (Table 3). The results demonstrated correlations between CP and all PBDEs,except BDE-154 (not correlated with the other PBDEs). BDE-153 was correlated with Dec 602, Dec 603 and CP.A study on PBDEs 47,99 , and 153 metabolism mediated by human liver microsomes reported that only BDE-47 and BDE-99 were metabolized. This study provided a possible explanation for the high bioaccumulation rate of BDE-153 in humans (Lupton et al., 2009). Thehypothesis is that the correlation obtained could result from a similar behavior of these dechloranecompounds. Different results were obtained by de la Torre et al. (2012) when they evaluated the correlation between dechloranes and PBDEs in marine mammal samples for Brazil. They only reported correlations between DP and PBDEs. However, levels and relative concentration 
patternsof PBDEs were different. Siddique et al. (2012)alsoreported correlations between

382 PBDEs and DP for breast milk samples from Canada but not with a consistent pattern. The PBDE pattern was similar toour study although the levels were 5 times higher.

\subsection{Comparison of dechlorane and OCP levels in human serum}

Individual and $\sum_{5}$ of dechlorane or PBDE levels did not statistically differ between males and females. Age was not correlated with PBDE levels, in accordance with previous observations (Kalantzi et al., 2011), while significant correlations were found between age and Dec 603, CP and Mirexlevels (Table 3).When the samples were split in two groups $\left(n_{1}=n_{2}=24\right)$, with agerangesof 29-58 years for the first group and 59-86 years for the second group, levels of Dec 603 and CP statistically differed $(p<0.05)$ with higher levels for the second group.

Because OCPs are persistant and bioaccumulative compounds, it is interesting to note that only Dec 603 and CP demonstrated relationships with some OCP levels already reported for these samples(Viel et al., 2011)Significant statistical correlations $(p<0.05)$ were found between Dec 603 and beta-HCH $\left(r_{s}=0.35\right)$, Dec 603 and trans-nonachlor $\left(r_{s}=0.36\right), \mathrm{CP}$ and beta- $\mathrm{HCH}\left(r_{s}=0.33\right)$ as well as $\mathrm{CP}$ and trans-nonachlor $\left(r_{s}=0.35\right)$. Beta- $\mathrm{HCH}$ is considered as a byproduct (5-14\%) of gamma-HCH (of Lindane), a well-used pesticide. Beta-HCH isomer correlated with Dec 603 and CP while no correlation was found with the gamma- isomer. Some studies reported greater bioaccumulation of the beta-isomer over the gamma-isomer (Kolarikova et al., 2013). A similar behavior was observed with trans-nonachlor. Although trans-and cis-nonachlor are both chlordane derivatives, correlations were found only with the trans-isomer. Some studies have already reported higher bioaccumulation of the transisomer over the cis-isomer (Bondy et al., 2000). Also, food web magnification factors (FWMFs) were determined for beta-HCH and trans-nonachlor (Skarphedinsdottir et al., 
2010). The correlation of Dec 603 and CP with these specific OCP isomers could be related to both exposure and bioaccumulation properties. Dec 603 and CPare known to be present as impurities in technical products. In the study of Shen et al. (2011), Dec 603 was observed in technical Aldrin and Dieldrin while CP was found only in technical Chlordene and Chlordane, at levels lower than 1\%.The higher levels of Dec 603 in the Lake Erie of Canada were suggested to be related to the use of Aldrin and Dieldrin.Lower levels of CP were detected compared to Dec 603 in our samples which is similar to other studies on dechlorane levels including CP. However, in terms of exposure, Aldrin, Dieldrin or Chlordane were banned in France in 1992 (INERIS, 1992). Results of monitoring studies performed in 2000 and 2005 were optimistic for the eradication of these pesticides (INERIS, 2007)and to our knowledge, no preferential use of Aldrin or Eldrin over Chlordane was reported.

\subsection{Levels of DP isomers}

Syn- and anti-DP isomers were analyzed separately. Higher levels and frequency of detection were obtained for the anti-isomer (Table 1). The anti-DP fraction $\left(f_{\text {anti, }}\right.$ amount of anti-DP in total DP) was calculated for 33 samples and ranged from 0.65 to 0.86 , with a mean value of $0.75 \pm 0.07$ (RSD $=9.3 \%)$. In several studies, the $f_{\text {anti }}$ value was compared with the reported ratio of commercial DP products, to assess potential differences between isomers behavior. According to Ben et al.(2013), the technical DP $f_{\text {anti }}$ value should be comprised between 0.60 and 0.80 , based on variation reportedfrom various batches or manufacturers (Hoh et al., 2006). Our results are included in this range and therefore support the hypothesis of nospecific isomer bioaccumulation, although sources of exposure for Europe have not been identified yet. However, the evaluation of a potential isomer bioaccumulation based on 
sample measurements and technical values comparison should be done carefully. A study on rats and DP exposure reported similar $f_{\text {anti }}$ values that ranged between 0.75 and 0.80 for muscle, liver and serum samples but it was also demonstrated that theseDP $f_{\text {anti }}$ values decreased significantly with higher levels of exposure (Li et al., 2013). A similar behavior was obtained for the study on Peregrine Falcon eggs sampled in Spain and Canada (Guerra et al., 2011). Lower DP $f_{\text {anti }}$ values were obtained for samples from Canada, when the DP levels were 10 to 50 times higher than levels reported in Spain. Both $f_{\text {anti }}$ value and DP level should be taken into consideration for the evaluation of a potential stereoselective bioaccumulation.

\section{CONCLUSIONS}

This study is the first report of $\sum_{5}$ dechlorane levels in Western European (France) human serum. Despite the fact thatno production sources have been identified in Europe to date,DP and related dechloranes were detected. A specific pattern of contamination was found, and Dec 603 was reported with high levels, compared to other biota samples that have been analyzed from Europe. Results demonstrated that bioaccumulation properties should be taken in consideration in addition to possible routes of human exposure.Dose-toxicity data are needed for these chemicals in order to initiate proper human risk assessment. The hypothesis of long range transport has also to be considered until more information on production and use are made available for Europe. Nevertheless, our study indicates that at least part of the European population might be exposed to dechloranes. This is further supported by recent levels reported from a preliminary study performed in Norway (Cequier et al., 2013). In addition, the $\sum_{5}$ dechlorane level is higher than the $\sum_{5}$ PBDE level. Because unregulated dechloranesare reported to present similar physico-chemical properties and 
455 for human biomonitoring.

456

\section{Acknowledgements}

458 The DP standard solutionsand the GC column were kindly provided by Cambridge Isotope 459 Laboratories (CIL, Andover, MS, USA) and Phenomenex (Utrecht, The Netherlands), 460 respectively. 
Akins JR, Waldrep K, Bernet JT Jr. The estimation of total serum lipids by a completely enzymatic 'summation' method. Clin. Chim. Acta 184: 219-226; 1989

Antignac JP, Cariou R, Zalko D, Berrebi A, Cravedi JP, Maume D, et al. Exposure assessment of French women and their newborn to brominated flame retardants: determination of tri- to deca- polybromodiphenylethers (PBDE) in maternal adipose tissue, serum, breast milk and cord serum. Environ Pollut. 157:164-73; 2009

Baron E, Eljarrat E, Barcelo D. Analytical method for the determination of halogenated norbornene flame retardants in environmental and biota matrices by gas chromatography coupled to tandem mass spectrometry. J Chromatogr A. 1248:154$60 ; 2012$

Ben YJ, Li XH, Yang YL, Li L, Di JP, Wang WY, et al. Dechlorane Plus and its dechlorinated analogs from an e-waste recycling center in maternal serum and breast milk of women in Wenling, China. Environ Pollut. 173:176-81; 2013

Betts K. New data on a widely used flame retardant. Environ Sci Technol. 42:5-6; 2008

Bondy GS, Newsome WH, Armstrong CL, Suzuki CA, Doucet J, Fernie S, et al. trans-Nonachlor and cis-nonachlor toxicity in Sprague-Dawley rats: comparison with technical chlordane. Toxicol Sci. 58:386-98; 2000

CanadianEnvironmental Protection Act,1999. Environmental Registry, Substances List. [Available at: http://www.ec.gc.ca/CEPARegistry/subs_list/NonDomestic.cfm. Accessed July 2013] 
Cequier E, Marcé RM, Becher G, Thomsen C. Determination of emerging halogenated flame retardants and polybrominated diphenyl ethers in serum by gas chromatography mass spectrometry. J Chromatogr A. 1310:126-32; 2013

Chovancova J, Conka K, Fabisikova A, Sejakova ZS, Domotorova M, Drobna B, et al. PCDD/PCDF, dl-PCB and PBDE serum levels of Slovak general population. Chemosphere. 88:1383-9; 2012

de la Torre A, Alonso MB, Martinez MA, Sanz P, Shen L, Reiner EJ, et al. Dechlorane-related compounds in franciscana dolphin (Pontoporia blainvillei) from southeastern and southern coast of Brazil. Environ Sci Technol. 46:12364-72; 2012

de la Torre A, Sverko E, Alaee M, Martinez MA. Concentrations and sources of Dechlorane Plus in sewage sludge. Chemosphere. 82:692-7; 2011

Feo ML, Baron E, Eljarrat E, Barcelo D. Dechlorane Plus and related compounds in aquatic and terrestrial biota: a review. Anal Bioanal Chem. 404:2625-37; 2012

Focant JF, Eppe G, Massart AC, Scholl G, Pirard C, De Pauw E. High-throughput biomonitoring of dioxins and polychlorinated biphenyls at the sub-picogram level in human serum. J Chromatogr A. 1130:97-107; 2006

Focant JF, Eppe G, Pirard C, De Pauw E. Fast clean-up for polychlorinated dibenzo-p-dioxins, dibenzofurans and coplanar polychlorinated biphenyls analysis of high-fat-content biological samples. J Chromatogr A. 925:207-21; 2001

Frederiksen M, Vorkamp K, Thomsen M, Knudsen LE. Human internal and external exposure to PBDEs - a review of levels and sources. Int J Hyg Environ Health. 212:109-34; 2009

Frery N, Volatier JL, Zeghnoun A, Falq G, Mouajjah S, Thebault A, et al. The french dioxin and incinerators study : method of the study. Organohalogen Compd. 69:2276-9; 2007 
Guerra P, Fernie K, Jimenez B, Pacepavicius G, Shen L, Reiner E, et al. Dechlorane Plus and Related Compounds in Peregrine Falcon (Falco peregrinus) Eggs from Canada and Spain. Environ Sci Technol. 45:1284-90; 2011

Guvenius DM, Aronsson A, Ekman-Ordeberg G, Bergman A, Noren K. Human prenatal and postnatal exposure to polybrominated diphenyl ethers, polychlorinated biphenyls, polychlorobiphenylols, and pentachlorophenol. Environ Health Perspect. 111:1235$41 ; 2003$

He S, Li M, Jin J, Wang Y, Bu Y, Xu M, et al. Concentrations and trends of halogenated flame retardants in the pooled serum of residents of Laizhou Bay, China. Environ Toxicol Chem. 32:1242-7; 2013

Hites RA, Salamova A, Venier M. Dechlorane Plus in Great Lakes air. Organohalogen Compd. $72: 423-6 ; 2010$

Hoh E, Zhu, Hites RA. Dechlorane Plus, a Chlorinated Flame Retardant, in the Great Lakes. EnvironSci Technol. 40:1184-9; 2006

$\begin{array}{lll}\text { INERIS,1992. } & \text { Executive } & \text { 92-1074. }\end{array}$ at :http://www.ineris.fr/aida/consultation_document/3193. Accessed July 2013]

INERIS, 2007. Données technico-économiques sur les substances chimiques en France. [Available at: http://rsde.ineris.fr/. Accessed July 2013]

International Programme on Chemical Safety: Environmental Health Criteria 44, Mirex, 1984. [Available at: http://www.inchem.org/documents/ehc/ehc/ehc44.htm. Accessed July 2013]

Kaiser KLE. Pesticide Report: The rise and fall of mirex. EnvironSciTechnol. 12:520-8; 1978 
Kalantzi OI, Geens T, Covaci A, Siskos PA. Distribution of polybrominated diphenyl ethers (PBDEs) and other persistent organic pollutants in human serum from Greece. Environ Int. 37:349-53; 2011

Kang J-H, Chang Y-S. Organochlorine Pesticides in Human Serum. in: Stoytcheva P.M., ed. Pesticides - Strategies for Pesticides Analysis; 2011

Kang JH, Kim JC, Jin GZ, Park H, Baek SY, Chang YS. Detection of Dechlorane Plus in fish from urban-industrial rivers. Chemosphere. 79:850-4; 2010

Kolarikova $\mathrm{K}$, von Tümpling $\mathrm{W}$, Bartels $\mathrm{P}$. Bioaccumulation of $\mathrm{HCH}$ isomers in selected macroinvertebrates from the Elbe River: sources and environmental implications. Environ Monit Assess. 185:4333-46; 2013

Lee SJ, Ikonomou MG, Park H, Baek SY, Chang YS. Polybrominated diphenyl ethers in blood from Korean incinerator workers and general population. Chemosphere. 67:489-97; 2007

Li Y, Yu L, Wang J, Wu J, Mai B, Dai J. Accumulation pattern of Dechlorane Plus and associated biological effects on rats after $90 \mathrm{~d}$ of exposure. Chemosphere. 90:2149$56 ; 2013$

Lupton SJ, McGarrigle BP, Olson JR, Wood TD, Aga DS. Human liver microsome-mediated metabolism of brominated diphenyl ethers 47, 99, and 153 and identification of their major metabolites. Chem Res Toxicol. 22:1802-9; 2009

Möller A, Xie Z, Sturm R, Ebinghaus R. Large-scale distribution of dechlorane plus in air and seawater from the Arctic to Antarctica. Environ Sci Technol. 44:8977-82; 2010

Munoz-Arnanz J, Roscales JL, Vicente A, Aguirre JI, Jimenez B. Dechlorane Plus in eggs of two gull species (Larus michahellis and Larus audouinii) from the southwestern Mediterranean Sea. Anal Bioanal Chem. 404:2765-73; 2012 
553

554

555

556

557

558

559

560

561 at:http://www.oxy.com/OurBusinesses/Chemicals/Products/Documents/dechlorane plus/dechlorane_plus.pdf. Accessed July 2013].

Pirard C, De Pauw E, Focant JF. New strategy for comprehensive analysis of polybrominated diphenyl ethers, polychlorinated dibenzo-p-dioxins, polychlorinated dibenzofurans and polychlorinated biphenyls by gas chromatography coupled with mass spectrometry. J Chromatogr A. 998:169-81; 2003

Qi H, Liu L, Jia H, Li YF, Ren NQ, You H, et al. Dechlorane Plus in surficial water and sediment in a northeastern Chinese river. Environ Sci Technol. 44:2305-8; 2010

Qiu X, Hites RA. Dechlorane Plus and Other Flame Retardants in Tree Bark from the Northeastern United States. Environ Sci Technol. 42:31-6; 2007

Ren G, Yu Z, Ma S, Li H, Peng P, Sheng G, et al. Determination of Dechlorane Plus in serum from electronics dismantling workers in South China. Environ Sci Technol. 43:9453-7; 2009

Shen L, Jobst KJ, Helm PA, Reiner EJ, McCrindle R, Tomy GT, et al. Identification and determination of the dechlorination products of Dechlorane 602 in Great Lakes fish and Arctic beluga whales by gas chromatography-high resolution mass spectrometry. Anal Bioanal Chem. 404:2737-48; 2012

Shen L, Reiner EJ, MacPherson KA, Kolic TM, Helm PA, Richman LA, et al. Dechloranes 602, 603, 604, Dechlorane Plus, and Chlordene Plus, a newly detected analogue, in tributary sediments of the Laurentian Great Lakes. Environ Sci Technol. 45:693-9; 2011 
Shen L, Reiner EJ, MacPherson KA, Kolic TM, Sverko E, Helm PA, et al. Identification and screening analysis of halogenated norbornene flame retardants in the Laurentian Great Lakes: Dechloranes 602, 603, and 604. Environ Sci Technol. 44:760-6; 2010

Siddique S, Xian Q, Abdelouahab N, Takser L, Phillips SP, Feng YL, et al. Levels of dechlorane plus and polybrominated diphenylethers in human milk in two Canadian cities. Environ Int. 39:50-5; 2012

Sjödin A, Jones RS, Focant JF, Lapeza C, Wang RY, McGahee EE, 3rd, et al. Retrospective timetrend study of polybrominated diphenyl ether and polybrominated and polychlorinated biphenyl levels in human serum from the United States. Environ Health Perspect. 112:654-8; 2004

Skarphedinsdottir H, Gunnarsson K, Gudmundsson GA, Nfon E. Bioaccumulation and biomagnification of organochlorines in a marine food web at a pristine site in Iceland. Arch Environ Contam Toxicol. 58:800-9; 2010

Stockholm

Convention,

2011.

[Available

at: http://chm.pops.int/Portals/0/Repository/convention_text/UNEP-POPS-COPCONVTEXT-FULL.English.PDF. Accessed July 2013].

Sühring R, Moller A, Freese M, Pohlmann JD, Wolschke H, Sturm R, et al. Brominated flame retardants and dechloranes in eels from German Rivers. Chemosphere. 90:118-24; 2013

Sverko E, Tomy GT, Marvin CH, Zaruk D, Reiner E, Helm PA, et al. Dechlorane Plus Levels in Sediment of the Lower Great Lakes. Environ Sci Technol. 42:361-6; 2007

Sverko E, Tomy GT, Reiner EJ, Li YF, McCarry BE, Arnot JA, et al. Dechlorane plus and related compounds in the environment: a review. Environ Sci Technol. 45:5088-98; 2011 
US Environmental Protection Agency: High Production Volume Information System(HPVIS), 2006. [Available at: http://www.epa.gov/hpvis/index.html. Accessed July 2013].

Viel JF, Floret N, Deconinck E, Focant JF, De Pauw E, Cahn JY. Increased risk of non-Hodgkin lymphoma and serum organochlorine concentrations among neighbors of a municipal solid waste incinerator. Environ Int. 37:449-53; 2011

Wang DG, Alaee M, Sverko E, Li YF, Reiner EJ, Shen L. Analysis and occurrence of emerging chlorinated and brominated flame retardants in surficial sediment of the Dalian coastal area in China. J Environ Monit. 13:3104-10; 2011

Wang DG, Yang M, Qi H, Sverko E, Ma WL, Li YF, et al. An Asia-specific source of dechlorane plus: concentration, isomer profiles, and other related compounds. Environ Sci Technol. 44:6608-13; 2010

Xian Q, Siddique S, Li T, Feng YL, Takser L, Zhu J. Sources and environmental behavior of dechlorane plus-a review. Environ Int. 37:1273-84; 2011

Yan X, Zheng J, Chen KH, Yang J, Luo XJ, Yu LH, et al. Dechlorane Plus in serum from e-waste recycling workers: influence of gender and potential isomer-specific metabolism. Environ Int. 49:31-7; 2012

Yu Z, Lu S, Gao S, Wang J, Li H, Zeng X, et al. Levels and isomer profiles of Dechlorane Plus in the surface soils from e-waste recycling areas and industrial areas in South China. Environ Pollut. 158:2920-5; 2010

Zheng J, Wang J, Luo XJ, Tian M, He LY, Yuan JG, et al. Dechlorane Plus in human hair from an e-waste recycling area in South China: comparison with dust. Environ Sci Technol. 44:9298-303; 2010 